\title{
SCIDiC
}

\author{
International Journal of Dentistry and Oral Science (IJDOS) \\ ISSN: 2377-8075
}

\section{Assessment Of Preferred Day For Dental Visits Among Pediatric Dental Patients}

Research Article

Keerthika. $\mathrm{S}^{1}$, Jessy $\mathrm{P}^{2 *}$, Santhosh Kumar $^{3}$

${ }^{1}$ Saveetha Dental College and Hospitals, Saveetha Institute of Medical and Technical Sciences, Chennai - 600 077, TN, India.

${ }^{2}$ Senior Lecturer, Department of Pedodontics, Saveetha Dental College, Saveetha Institute of Medical and Technical Sciences, Saveetha University, 162, Poonamallee High Road, Chennai - 600077, Tamil Nadu, India.

${ }^{3}$ Reader, Department of Oral and Maxillofacial Surgery, Saveetha Dental College, Saveetha Institute of Medical and Technical Sciences, Saveetha University, 162, Poonamallee High Road, Chennai - 600077, Tamil Nadu, India.

\section{Abstract}

The practice of modern pediatric dentistry requires delivery of quality care. The appointment scheduling lies at the intersection of efficiency and timely access to health services. Timely access is important for realizing good medical outcomes. The aim of the study is to evaluate the preferred day chosen for dental care among pediatric dental patients. It is a university setting study, case sheets of paediatric patients reported were reviewed. Information about the patient's Name, age, Day of reporting to the college were collected. The obtained data was entered in MS excel based on day wise i.e Sunday,Saturday and weekday in a methodical manner and imported in SPSS software. Chi square test was applied and level of significance set at $\mathrm{p}<0.05$. The results have proved that 2 to 6yrs old preferred visiting a dentist on sunday, 7-11 yrs preferred saturday and 12 to $17 \mathrm{yrs}$ old preferred visiting on all three days saturday, sunday and weekdays. There was a statistically significant association between age group and day preferred $(\mathrm{P}<0.05)$. While comparing gender and day preferred it was found that Male patient flow was higher during Saturdays $(26.5 \%)$. Female patient flow was higher during Sundays (16.5\%). There was a significant association between gender and day preference for dental visits among the pediatric population. As weekends are more preferred for dental visits among children, the real challenge would be to provide maximum possible levels of satisfaction to the patients in relation to all aspects of the health care delivery system so that the needs of the patients can be met on time which will avoid the delay in dental treatment.

Keywords: Appointment; Dental Care; Children; Day Preference; Patient Need.

\section{Introduction}

Children are the country's greatest resources [1, 2]. Pediatric dentistry is a unique speciality of dentistry as the patient, in the said case a child patient,cannot come alone to the dental clinic for his/ her treatment but has to be brought by parents who seek dental care for their child. Most children often consider dentists as pain imparting tooth puller primary responsibility of pediatric dentists to provide quality oral health care to patients [3, 4]. Studies show dental care for children should be given at certain times of the day. This helps pediatric dentists to establish a friendly relationship with children thereby combat fears and deliver effective and efficient treatment $[5,6]$. Factors that may have contributed for performing better dental care includes convenient hour of the day to dental clinic,having rested child,being aware of the lack of fatigue,thirst, and hunger of the children studies show that appropriate appointment for kid's oral care between 10:30 to 12:00 in the morning and 17:00 to 19:00 in the early hours of evening. $[7,8]$. This is because in the early hours of the morning,children suffer sleepiness,nagging and uncooperative to dental treatment $[9,10]$.

Another factor that influences dental day preference among pediatric patients is parental reflect national institute, if parents or carers have access to but persistently fail to obtain, national health system treatment for their child's dental care [11, 12]. Many studies report that socio-economic and ethnic differences play a role in obtaining appropriate dental care. Instead of adults choosing

\footnotetext{
*Corresponding Author:

Jessy P,

Senior Lecturer, Department of Pedodontics, Saveetha Dental College, Saveetha Institute of Medical and Technical Sciences, Saveetha University, 162, Poonamallee High Road,

Chennai - 600077, Tamil Nadu, India.

Tel: 8861646189

E-mail: nivedhigaab.sdc@saveetha.com

Received: May 28, 2021

Accepted: June 16, 2021

Published: July 03, 2021

Citation: Keerthika. S, Jessy P, Santhosh Kumar. Assessment Of Preferred Day For Dental Visits Among Pediatric Dental Patients. Int J Dentistry Oral Sci. $2021 ; 8(7): 3006-3010$. doi: http://dx.doi.org/10.19070/2377-8075-21000612

Copyright: Jessy $\mathbf{P}^{\circ}$ 2021. This is an open-access article distributed under the terms of the Creative Commons Attribution License, which permits unrestricted use, distribution and reproduction in any medium, provided the original author and source are credited.
} 
appropriate dental appointments for children,it would be beneficial to accept day and time preference of children [13, 14]. Studies have been conducted all over the world in an effort to devise and study patient appointment scheduling systems based on preferred day and the effectiveness of these systems in improving the quality of practice as also the level of patient satisfaction. The appointment scheduling lies at the intersection of efficiency and timely access to health services. Timely access is important for realizing good medical outcomes. Since there is a lack of clarity in factors such as parents preferences towards day,time factor, there is a quality of life in negligence of pediatric dental visits in our population. Previously our team has a rich experience in working on various research projects across multiple disciplines The [1327]. Hence the aim of the study is to evaluate the preferred day chosen for dental care among pediatric dental patients.

\section{Materials And Methods}

\section{Study setting}

This study was conducted in a university setting. Approval was obtained from the institutional Ethical committee.

\section{Sampling}

It is a retrospective study, data collected from June 2019 - April 2020. Totally 1000 case sheets were reviewed. Cross verification of data was done by the presence of additional reviewers through photographic evaluation. Consecutive sampling done to minimise sampling bias. It was generalised to patients below 18 years reported to the institution.

\section{Ethical approval}

The study was commenced after approval from the scientific review board, and the ethical clearance was obtained from the ethical committee of the University with the following ethical approval number- SDC/SIHEC/2020/DIASDATA/0619-0320

\section{Data Collection}

Inclusion criteria of the study includes patients below 18 yrs who had reported to the Department of Pedodontics and Preventive dentistry, Saveetha Dental College. Patient records with congenital diseases, medical emergency conditions, traumatic injuries, Incomplete or censored data were excluded from the study. Infor- mation about the patient's Name, age, gender, Day of reporting to the college were collected. The obtained data was entered in MS excel based on day wise i.e Sunday, Saturday and weekday in a methodical manner and imported in SPSS software.

\section{Analytics}

IBM SPSS 2.0 software was used for data analysis. Independent variables included in the study were systemic disease, age, gender of the subject. Dependent variables included patient preference, holiday. Descriptive statistics and Chi square test were applied and level of significance set at $\mathrm{p}<0.05$.

\section{Results And Discussion}

In the current study, 855 paediatric patients participated after considering the exclusion criteria. The bar graph represented in figure 1 represents association between age group and day preference where 2 to 6yrs old preferred visiting a dentist on sunday $(9.27 \%)$, $7-11$ yrs preferred saturday $(29.49 \%)$ and 12 to $17 \mathrm{yr}$ old preferred visiting all three saturday (4.07\%), sunday (3.84\%) and weekday $(3.05 \%)$. There was a statistical significant difference between age group and day preferred $(\mathrm{p}<0.05)$. (Table 1$)$. While comparing gender and day preferred it was found that Male patient flow was higher during Saturdays (26.5\%). Female patient flow was higher during Sundays (16.5\%). There was significant correlation between gender and day preference for dental visits among the pediatric population $(\mathrm{p}<0.05)$ (Figure 2$)$. Among weekdays , male preferred on weekdays of about $(13.79 \%)$ and females $(8.59 \%)$. (Table 2).

Children are the country's greatest resources. Scheduling of appointments based on the preferred day is of utmost importance in a pediatric dental setup. It is mandatory to deliver quality health care in an effective and efficient manner to child patients. In addition, scheduling an appointment based on their preferred day for a child patient directly correlated to the parental preference. Timely access among children is important for realizing good medical outcomes. The world over,various systems have been devised and studied to improve the appointment scheduling systems based on their preferred day so as to render quality treatments to patients on time. Most of the systems have concluded that through appointment scheduling, preferred day can help to improve the quality of health care delivery, not all the systems have the Sunday access to pediatric dental care which fulfill the need of a child on time as they are school going.Also the parental pref-

Figure 1. The graph shows association between age and day preference, where $\mathrm{X}$ axis denotes the age group and $\mathrm{Y}$ axis denotes number of patients. Age group of 2 to 6 years preferred Sunday (blue) for dental visits. 7 to 11 years preferred Sunday (blue) and Saturday (green). There was a significant association between age group and day preference. (Pearson chi square $=14.713, p=0.023, p<0.05$, statistically significant). 2 to 11 yrs old children reported preferably on weekends for dental visits.

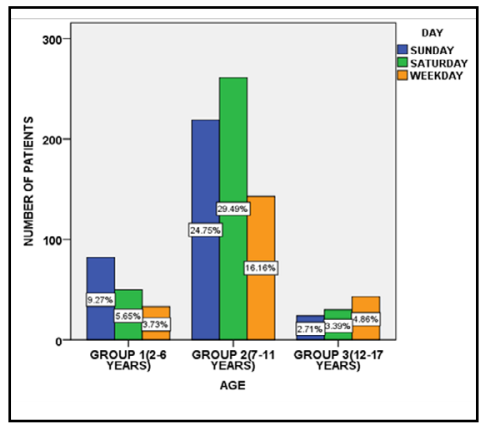


Figure 2. The graph represents association between gender and day preference, where $\mathrm{X}$ axis denotes the gender and $\mathrm{Y}$ axis denotes number of patients. It was observed that boys predominantly preferred saturdays (green) while the girls (blue) preferred sundays. There was a significant association between gender and day preference for dental visits among the pediatric population (Chi square tests, $\mathrm{p}$ $0.042, \mathrm{p}<0.05$, statistically significant).

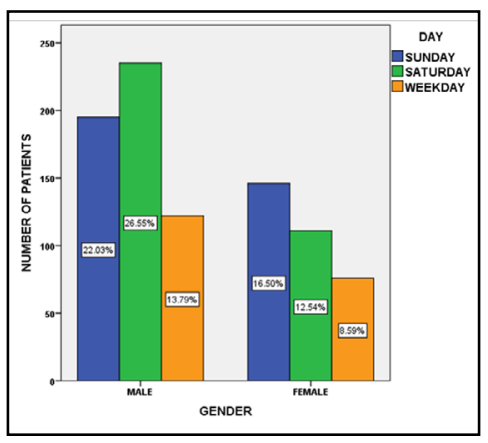

Table 1. Table represents association between age groups and day preference.

\begin{tabular}{|c|c|c|c|c|c|c|c|}
\hline Variables & \multicolumn{6}{|c|}{ Day Preference of pediatric patient } & Statistical Values \\
\hline \multirow{2}{*}{ Age (in yrs) } & \multicolumn{2}{|c|}{ Sunday } & \multicolumn{2}{|c|}{ Saturday } & \multicolumn{2}{|c|}{ Weekdays } & \multirow{2}{*}{$\begin{array}{c}\text { Pearson Chi square } \\
=14.713\end{array}$} \\
\hline & $\mathbf{n}$ & $(\%)$ & $\mathbf{n}$ & $(\%)$ & $\mathbf{n}$ & $(\%)$ & \\
\hline Group 1(2-6 yrs) & 90 & $-9.20 \%$ & 52 & $-5.60 \%$ & 43 & $-3.70 \%$ & \\
\hline Group2(7-11 yrs) & 197 & $-24 \%$ & 259 & $(29.4 \%$ & 133 & $-16.10 \%$ & $\mathrm{P}$ value $=0.023^{*}$ \\
\hline Group3(12-17 yrs) & 41 & $-3.80 \%$ & 33 & $(4.07 \%$ & 37 & $-3.10 \%$ & \\
\hline
\end{tabular}

*(statistically significant)

Table 2. Table representing association between gender and day preference.

\begin{tabular}{|c|c|c|c|c|c|}
\hline Variables & \multicolumn{4}{|c|}{ Day preference of Pediatric dental Patients } & \multirow{2}{*}{ Statistical values } \\
\cline { 2 - 5 } Days & \multicolumn{2}{|c|}{ Male } & \multicolumn{2}{|c|}{ Female } & \\
\cline { 2 - 5 } & $\mathbf{n}$ & $\mathbf{( \% )}$ & $\mathbf{n}$ & $\mathbf{( \% )}$ & \multirow{2}{*}{$\begin{array}{c}\text { Pearson chi square } \\
\text { value }=6.357\end{array}$} \\
\hline Sunday & 274 & $(22.30 \%)$ & 180 & $(16.50 \%)$ & \\
\hline Saturday & 175 & $(26.50 \%)$ & 76 & $(12.50 \%)$ & P value $=0.042^{*}$ \\
\hline Weekdays & 111 & $(13.79 \%)$ & 69 & $(8.50 \%)$ & \\
\hline
\end{tabular}

(*statistically significant)

erence to bring their child for dental visits during saturday and sunday are comparatively higher than weekdays specially in case of working parents. Hence the parental satisfaction with these system quite higher.

In our study the middle school group 7 to 11 yrs of age preferred both Sunday and saturday at the highest when compared to the week days. This clearly shows unmet dental needs, little attention has been given to promotion of oral health and primary prevention of dental disease by parents in this group of population. This is Supported by Study by Stare et al which $45.1 \%$ of children denied dental care due to parental neglect where the causative factor was found to be working parents $[28,29,6,30,31,8]$.

Based on gender, the prevalence of male group of Pediatric patients visited more on saturday, while the females visited sunday the highest which shows statistical significant difference among gender, this is in accordance with another study done by Dodd et al which states adolescent female patients required accompany of friends or parents to dental clinic. $[32,33,20]$ hence majority of girl parents preferred sunday where they can accompany on sunday leisurely due to reason behind working parents. Also, many patients feel safe and relaxed in the presence of their parents which will tend to co-operated well for dental treatments.[34, 35].

In the present study most of the children preferred weekends predominantly sundays than weekdays which is in accordance with the study done by Crosby et al which recognized that during weekdays children themselves prioritize working, playing with their friends, going to school than visiting dentists $[36,18]$. Obstacles for upper school children to dental visit is school work however prioritizing dental care over school differs for children to children. Contrary to results Crocombe reported that some children wanted to visit dental clinics during school time $[37,26]$.

Appointments during weekday either before or after school time makes children tired and sleepy [38, 39]. Therefore both the time of the dental appointment and the length of the visit was important for participants' motivation to keep their appointment at the dental clinic [40]. Another possible obstacle reported transporta- 
tion difficulties. Many parents take their children to the dentist with greater transportation difficulty taking several buses to get to the clinic as nearby access on Sunday becomes at most difficult $[39,41,30]$. Our institution is passionate about high quality evidence based research and has excelled in various fields ( [42-52]. Based on the results of the present study other systems also should consider paediatric dental care and access towards appointments on Sundays to provide effective treatment among the pediatric population on time without delay. Most research on appointment scheduling using different parameters like occupation of parents and their correlation with parent satisfaction needs to be conducted.

\section{Conclusion}

Within the limits of our study, it was found that the middle school group children aged 7 to 11 yrs preferred both Sunday and Saturday for dental care. Most of the 2 to 6 yrs old children reported on sunday for dental care. This study revealed that parents who felt overloaded in daily life did not prioritize taking their children for dental care during weekdays. Day of dental appointments play an important role in motivating Pediatric patients to keep their appointment at the dental clinic. Hence other systems also consider paediatric dental care and appointments on Sundays to provide effective treatment among the pediatric population without any delay.

\section{Acknowledgements}

We would like to thank the administration of Saveetha University, Chennai for granting us the clearance to conduct this study.

\section{Authors Contribution}

Jessy P contributed to study conception and design, data collection, analysis and interpretation and drafted the work. S.Keerthika contributed to data interpretation, study design and data collection. Santhosh Kumar contributed to Study conception and design and data collection. All authors critically reviewed the manuscript and approved the final version.

\section{References}

[1]. Damle SG. Research in dentistry: The road less traveled. Contemp Clin Dent. 2012 Jan 1;3(1):1.

[2]. Jeevanandan G. Kedo-S Paediatric Rotary Files for Root Canal Preparation in Primary Teeth - Case Report. J Clin Diagn Res. 2017 Mar;11(3):ZR03ZR05.Pubmed PMID: 28511532

[3]. Mittal R, Wong ML, Koh GC, Ong DLS, Lee YH, Tan MN, et al. Factors affecting dental service utilisation among older Singaporeans eligible for subsidized dental care - a qualitative study. BMC Public Health. 2019 Aug 8;19(1):1075.Pubmed PMID: 31395045.

[4]. Govindaraju L, Jeevanandan G, Subramanian EMG. Comparison of quality of obturation and instrumentation time using hand files and two rotary file systems in primary molars: A single-blinded randomized controlled trial. Eur J Dent. 2017 Jul-Sep;11(3):376-379.Pubmed PMID: 28932150.

[5]. Tam W, Lee RC, Lin B, Simon JC, Fried D. Assessment of simulated lesions on primary teeth with near-infrared imaging. Proc SPIE Int Soc Opt Eng. 2016 Feb 13.Pubmed PMID: 26997743.

[6]. Govindaraju L, Jeevanandan G, Subramanian EM. Knowledge and practice of rotary instrumentation in primary teeth among indian dentists: A questionnaire survey. J Int Oral Health. 2017 Mar 1;9(2):45.

[7]. Nowak A, Christensen JR, Mabry TR, Townsend JA, Wells MH, editors. Pediatric dentistry-E-book: Infancy through adolescence. Elsevier Health Sciences; 2018 May 10:656.
[8]. Somasundaram S, Ravi K, Rajapandian K, Gurunathan D. Fluoride Content of Bottled Drinking Water in Chennai, Tamilnadu. J Clin Diagn Res. 2015 Oct;9(10):ZC32-4.Pubmed PMID: 26557612.

[9]. Mandal M, Edelstein BL, Ma S, Minkovitz CS. Changes in state policies related to oral health in the United States, 2002-2009. J Public Health Dent. 2014 Fall;74(4):266-75.Pubmed PMID: 24650113

[10]. Jeevanandan G, Govindaraju L. Clinical comparison of Kedo-S paediatric rotary files vs manual instrumentation for root canal preparation in primary molars: a double blinded randomised clinical trial. Eur Arch Paediatr Dent. 2018 Aug;19(4):273-278.Pubmed PMID: 30003514.

[11]. Brill WA. Parents' assessment and children's reactions to a passive restraint device used for behavior control in a private pediatric dental practice. ASDC J Dent Child. 2002 Sep-Dec;69(3):310-3, 236.Pubmed PMID: 12613318.

[12]. Govindaraju L, Jeevanandan G, Subramanian E. Clinical Evaluation of Quality of Obturation and Instrumentation Time using Two Modified Rotary File Systems with Manual Instrumentation in Primary Teeth. J Clin Diagn Res. 2017 Sep;11(9):ZC55-ZC58.Pubmed PMID: 29207834.

[13]. Hafeez N. Accessory foramen in the middle cranial fossa. Res J Pharm Technol. 2016 Nov 1;9(11):1880.

[14]. Krishnan RP, Ramani P, Sherlin HJ, Sukumaran G, Ramasubramanian A, Jayaraj G, et al. Surgical Specimen Handover from Operation Theater to Laboratory: A Survey. Ann Maxillofac Surg. 2018 Jul-Dec;8(2):234-238. Pubmed PMID: 30693238.

[15]. Somasundaram S, Ravi K, Rajapandian K, Gurunathan D. Fluoride Content of Bottled Drinking Water in Chennai, Tamilnadu. J Clin Diagn Res. 2015 Oct;9(10):ZC32-4.Pubmed PMID: 26557612.

[16]. Felicita AS. Orthodontic extrusion of Ellis Class VIII fracture f maxillary lateral incisor - The sling shot method. Saudi Dent J. 2018 Jul;30(3):265-269. Pubmed PMID: 29942113.

[17]. Kumar S, Rahman RE. Knowledge, awareness, and practices regarding biomedical waste management among undergraduate dental students. Asian J Pharm Clin Res. 2017;10(8):341.

[18]. Gurunathan D, Shanmugaavel AK. Dental neglect among children in Chennai. J Indian Soc Pedod Prev Dent. 2016 Oct 1;34(4):364-9.

[19]. Sneha S. Knowledge and awareness regarding antibiotic prophylaxis for infective endocarditis among undergraduate dental students. Asian J. Pharm. Clin. Res. 2016 Oct 1:154-9.

[20]. Dhinesh B, Lalvani JI, Parthasarathy M, Annamalai K. An assessment on performance, emission and combustion characteristics of single cylinder diesel engine powered by Cymbopogon flexuosus biofuel. Energy Convers. Manag. 2016 Jun 1;117:466-74.

[21]. Choudhari S, Thenmozhi MS. Occurrence and Importance of Posterior Condylar Foramen. LATERALITY. 2016 Aug 28;8:11-43.

[22]. Paramasivam A, Vijayashree Priyadharsini J, Raghunandhakumar S. N6adenosine methylation (m6A): a promising new molecular target in hypertension and cardiovascular diseases. Hypertens Res. 2020 Feb;43(2):153154.Pubmed PMID: 31578458.

[23]. Wu F, Zhu J, Li G, Wang J, Veeraraghavan VP, Krishna Mohan S, et al. Biologically synthesized green gold nanoparticles from Siberian ginseng induce growth-inhibitory effect on melanoma cells (B16). Artif Cells Nanomed Biotechnol. 2019 Dec;47(1):3297-3305.Pubmed PMID: 31379212.

[24]. Palati S, Ramani P, Shrelin HJ, Sukumaran G, Ramasubramanian A, Don $\mathrm{KR}$, et al. Knowledge, Attitude and practice survey on the perspective of oral lesions and dental health in geriatric patients residing in old age homes. Indian J Dent Res. 2020 Jan-Feb;31(1):22-25.Pubmed PMID: 32246676.

[25]. Saravanan M, Arokiyaraj S, Lakshmi T, Pugazhendhi A. Synthesis of silver nanoparticles from Phenerochaete chrysosporium (MTCC-787) and their antibacterial activity against human pathogenic bacteria. Microb Pathog. 2018 Apr;117:68-72.Pubmed PMID: 29427709.

[26]. Govindaraju L, Gurunathan D. Effectiveness of Chewable Tooth Brush in Children-A Prospective Clinical Study. J Clin Diagn Res. 2017 Mar;11(3):ZC31-ZC34.Pubmed PMID: 28511505.

[27]. Vijayakumar Jain S, Muthusekhar MR, Baig MF, Senthilnathan P, Loganathan S, Abdul Wahab PU, et al. Evaluation of Three-Dimensional Changes in Pharyngeal Airway Following Isolated Lefort One Osteotomy for the Correction of Vertical Maxillary Excess: A Prospective Study. J Maxillofac Oral Surg. 2019 Mar;18(1):139-146.Pubmed PMID: 30728705.

[28]. Skaret E, Astrøm AN, Haugejorden O, Klock KS, Trovik TA. Assessment of the reliability and validity of the Dental Neglect Scale in Norwegian adults. Community Dent. Health. 2007 Dec;24(4):247-52. PMID: 18246843.

[29]. Ravikumar D, Jeevanandan G, Subramanian EM. Evaluation of knowledge among general dentists in treatment of traumatic injuries in primary teeth: A cross-sectional questionnaire study. Eur. J. Dent. 2017 Apr;11(02):232-7.

[30]. Coolidge T, Heaton LJ, Milgrom P. The challenge of sedation with adolescents: case studies and clinical recommendations. SAAD Dig. 2009 Jan;25:29-36

[31]. Panchal V, Jeevanandan G, Subramanian E. Comparison of instrumentation 
time and obturation quality between hand K-file, H-files, and rotary Kedo-S in root canal treatment of primary teeth: A randomized controlled trial. J Indian Soc Pedod Prev Dent. 2019 Jan-Mar;37(1):75-79.Pubmed PMID: 30804311 .

[32]. Dodd VJ, Logan H, Brown CD, Calderon A, Catalanotto F. Perceptions of oral health, preventive care, and care-seeking behaviors among rural adolescents. J Sch Health. 2014 Dec;84(12):802-9.Pubmed PMID: 25388597.

[33]. Aishwarya A, Gurunathan D. Stress level in dental students performing pedodontic procedure. J Adv Pharm Educ Res. 2017;7(1).

[34]. Ekman A. Dental health, dental health knowledge and behaviour in 14-yearold children of Finnish immigrant families in the north of Sweden. Swed Dent J. 1989;13(3):95-102.Pubmed PMID: 2756468.

[35]. Packiri S, Gurunathan D, Selvarasu K. Management of paediatric oral ranula: a systematic review. J Clin Diagn Res. 2017 Sep;11(9):ZE06-9.

[36]. Erridge PL. Cross infection, control in dentistry. A practical illustrated guide. J. Dent. 1994;22:96. Available from: http://dx.doi.org/10.1016/03005712(94)90009-4

[37]. Crocombe LA, Allen P, Bettiol S, Khan S, Godwin D, Barnett T, et al. Geographical variation in preventable hospital admissions for dental conditions: An Australia-wide analysis. Aust J Rural Health. 2019 Dec;27(6):520-526. Pubmed PMID: 31646693.

[38]. Christie WH. WILliam H. CHRISTIE, DMD, MS, FRCD(C), Professor (retired), Department of Restorative Dentistry, Faculty of Dentistry, University of Manitoba, Winnipeg, Canada [Internet]. Vol. 23, Endodontic Topics. 2010. p. 159-159. Available from: http://dx.doi.org/10.1111/etp.12009_7

[39]. Subramanyam D, Gurunathan D, Gaayathri R, Vishnu Priya V. Comparative evaluation of salivary malondialdehyde levels as a marker of lipid peroxidation in early childhood caries. Eur J Dent. 2018 Jan-Mar;12(1):67-70. Pubmed PMID: 29657527.

[40]. Nair M, Jeevanandan G, Vignesh R, Subramanian EM. Comparative evaluation of post-operative pain after pulpectomy with k-files, kedo-s files and mtwo files in deciduous molars-a randomized clinical trial. Braz. Dent. Sci. 2018 Oct 24;21(4):411-7.

[41]. Ramakrishnan M, Bhurki M. Fluoride, Fluoridated Toothpaste Efficacy And Its Safety In Children-Review. Int. J. Pharm. Sci. Res.. 2018 Oct $1 ; 10(04): 109-14$

[42]. Vijayashree Priyadharsini J. In silico validation of the non-antibiotic drugs acetaminophen and ibuprofen as antibacterial agents against red complex pathogens. J Periodontol. 2019 Dec;90(12):1441-1448.Pubmed PMID:
31257588.

[43]. PC J, Marimuthu T, Devadoss P, Kumar SM. Prevalence and measurement of anterior loop of the mandibular canal using CBCT: A cross sectional study. Clin Implant Dent Relat Res. 2018 Apr 6;20(4):531-4.

[44]. Ramesh A, Varghese S, Jayakumar ND, Malaiappan S. Comparative estimation of sulfiredoxin levels between chronic periodontitis and healthy patients - A case-control study. J Periodontol. 2018 Oct;89(10):1241-1248.Pubmed PMID: 30044495.

[45]. Ramadurai N, Gurunathan D, Samuel AV, Subramanian E, Rodrigues SJ. Effectiveness of 2\% Articaine as an anesthetic agent in children: randomized controlled trial. Clin Oral Investig. 2019 Sep;23(9):3543-50.

[46]. Sridharan G, Ramani P, Patankar S, Vijayaraghavan R. Evaluation of salivary metabolomics in oral leukoplakia and oral squamous cell carcinoma. J. Oral Pathol. Med. 2019 Apr;48(4):299-306.

[47]. Ezhilarasan D, Apoorva VS, Ashok Vardhan N. Syzygium cumini extract induced reactive oxygen species-mediated apoptosis in human oral squamous carcinoma cells. J Oral Pathol Med. 2019 Feb;48(2):115-121.Pubmed PMID: 30451321.

[48]. Mathew MG, Samuel SR, Soni AJ, Roopa KB. Evaluation of adhesion of Streptococcus mutans, plaque accumulation on zirconia and stainless steel crowns, and surrounding gingival inflammation in primary molars: randomized controlled trial. Clin Oral Investig. 2020 Sep;24(9):1-6.Pubmed PMID: 31955271

[49]. Samuel SR. Can 5-year-olds sensibly self-report the impact of developmental enamel defects on their quality of life?. Int J Paediatr Dent. 2021 Mar;31(2):285-6.

[50]. R H, Ramani P, Ramanathan A, R JM, S G, Ramasubramanian A, et al. CYP2 C9 polymorphism among patients with oral squamous cell carcinoma and its role in altering the metabolism of benzo[a]pyrene. Oral Surg Oral Med Oral Pathol Oral Radiol. 2020 Sep;130(3):306-312.Pubmed PMID: 32773350.

[51]. Chandrasekar R, Chandrasekhar S, Sundari KKS, Ravi P. Development and validation of a formula for objective assessment of cervical vertebral bone age. Prog Orthod. 2020 Oct 12;21(1):38.Pubmed PMID: 33043408.

[52]. Vijayashree Priyadharsini J, Smiline Girija AS, Paramasivam A. In silico analysis of virulence genes in an emerging dental pathogen A. baumannii and related species. Arch Oral Biol. 2018 Oct;94:93-98.Pubmed PMID: 30015217. 